\title{
Factors Affecting SME Owners in Adopting ICT in Business using Thematic Analysis
}

\author{
Anis Nur Assila Rozmi ${ }^{1}$, Puteri N.E. Nohuddin ${ }^{2}$ \\ Institute of IR4.0, Universiti Kebangsaan Malaysia \\ Bangi, Malaysia \\ Universiti Kuala Lumpur British Malaysian Institute, \\ Gombak, Selangor
}

\author{
Abdul Razak Abdul $\mathrm{Hadi}^{3}$ \\ Universiti Kuala Lumpur Business School \\ Kuala Lumpur, Malaysia
}

\author{
Mohd Izhar A. Bakar ${ }^{4}$ \\ Universiti Kuala Lumpur British Malaysian Institute \\ Gombak, Malaysia
}

A. Imran Nordin ${ }^{5}$

CIMB

Kuala Lumpur, Malaysia

\begin{abstract}
In Malaysia, Small Medium Enterprise (SME) has become the main contributor for the income generation and employment thus are expected to increase country's GDP growth. Hence, it is important for the SME owners to ensure the sustainability of their business in today's business settings that has moved to digital businesses in which technology is used to create new value in business models, customer experiences and the internal capabilities that support its core operations. Yet, there are still local SMEs who did not fully utilized the advantages of adopting Information and Communications Technology (ICT) in their business operation and transactions. This paper presents an interview done with 12 SME owners that operates their businesses in Kuala Lumpur and Selangor. The study is to gain an understanding on the factors affecting SME owners in adopting ICT in their business by using the Thematic Analysis method. The outcome shows that there are two central themes that affect ICT usage in SME which are the (1) Internal Factor and (2) External Factor. Further, we identified two (2) components that effect the Internal Factor, namely Company (capital, company's age, less skilled workers and family business) and SME Owners (time, education, perceptions and experiences) and another two (2) components that affect the External Factor, namely Technology (high cost, complicated, system's security and stability) and Regulators (government's initiatives, training skills and no urgency). Hence, the result is important to the SME owners and management as well as the government or the authorities to resolve these issues in order to increase the ICT usage among the SME owners in Malaysia.
\end{abstract}

Keywords-Small Medium Enterprise (SME); Information and Communications Technology (ICT); thematic analysis; internal factors; external factor

\section{INTRODUCTION}

With the advancement of computer technology, businesses are urged to adopt ICT in order to keep abreast of technology development and maintain its sustainability. The ICT is widely used in all sectors including business, especially in Malaysia. In today's business operation and transactions, ICT are made reliable to every person. Thus, SME owners are encouraged to choose for this option as argued by [40], there are still SMEs in the rural areas who did not fully utilized ICT usage in their business. The disadvantages to the business are that it will be less competitive [31], less productivity [4] and lagged behind [23]. The technology revolution has forced everyone to stay ahead of the technology to experience the advantages [44] of using it.

It is not an easy task to ensure SMEs in Malaysia to fully adopt ICT for their businesses. There are several factors that contribute to the low adoption of the ICT in SME. Issues such as lack of ICT knowledge [42] and limited budget for an ICT investment [5] have been identified as the main barrier for SME owners to adopt ICT. Moreover, individual capabilities have a huge effect on the adoption as well. The unpleasant past experiences in handling ICT [47] can also change SME owner's perception to fully adopt ICT. Thus, the existing issues need to be highlighted first by the SME owners and the government in order to increase the ICT adoption amongst SMEs in Malaysia. The objective of this study is to identify factors that affect SME owners to adopt ICT for their businesses. This study uses thematic analysis method through interview sessions with twelve (12) SME owners in Kuala Lumpur and Selangor, Malaysia.

The rest of the paper is organized as follows. Section 2 discusses the background of several topics that are related to ICT, SME, Thematic Analysis, Impact on ICT Diffusion and Factors Affecting SME owners to adopt ICT. Then Section 3 provides a description of the methodology of the proposed framework for Thematic Analysis. This is followed by Section 4 with a demonstration of the experimental results and findings. Finally, in Sections 5 and 6, the paper is concluded with a brief discussion and the future research work.

\section{BACKGROUND AND RELATED WORK}

\section{A. Information and Communication Technology in Business}

ICT is the terminology for processing and communicating information. ICT is divided into two, namely information technology and communication technology. The scope of ICT covers everything related to storage, retrieve, manipulate, transmit or receive information electronically in digital form such as personal computers, digital televisions, emails and 
robots. The ICT is expanding globally and the development is expected to contribute in all areas especially in business. The reason is because, ICT is one of the sources of economic growth of the country. Furthermore, it is found that the use of ICT in business in improving access to customers and other business partners as well as to improve business performance to achieve to the optimum level [35]. Businesses use computers and software to run their operations more smoothly. They utilize ICT in various departments namely finance, manufacturing, human resources, and security [26].

\section{B. Small Medium Enterprise in Malaysia}

According to [9], 907,065 organizations (98.5\%) registered in Malaysia are SMEs. The sectors in the SMEs were Services (89.2\%), Manufacturing (5.3\%), Construction (4.3\%), Agriculture (1.1\%) and Mining \& Quarrying $(0.1 \%)$. For the Manufacturing sector, it is considered as SMEs if the companies' annual sales do not exceed RM50 million or fulltime employees do not exceed 200 people. For the Services and other sectors, their annual sales do not exceed RM20 million or full-time employees do not exceed 75 people. SME is defined based on company's annual sales or full-time employees. The advantages of having many SMEs in the country are to ensure the country's economic growth [30] and offer employability [16] to the nation. A research by [37] discovered that the initiative of the public university in promoting entrepreneurial activities is a good move. This is to inculcate the interest and business mind set to the students in order to inspire them to set up a business as to reduce the number of unemployment in Malaysia.

\section{Factors Affecting ICT usage among SME Owners}

ICT plays an important role in improving business performance and profitability. However, the SME owner's attitude and knowledge in ICT are the key determinants of a business in accepting ICT [40]. Other factors that contribute to the low usage of ICT in SMEs are due to internal and external factors [20]. Internal factors include experience in ICT and organizational size. According to [8], the external factors that influence the use of ICT among SMEs are the industry structure, presence of technology service providers and regulation. In addition, [19] have listed other factors that also contribute to the adoption and use of ICT in business, which is an appropriate business plan, implementation strategy and requires in-depth knowledge of ICT.

There are also other studies that conclude that SME owners' expertise and involvement in ICT, supply chain features and government policy are important factors in shaping ICT acceptance among SMEs [20]. There are still doubts and challenges associated with privacy and security of ICT systems. There is a risk that the data made from all connected machines and devices, can ended up being misused [1]. On the other hand, [43] added that the factors affecting the ICT usage among the SME owners are the effort expectancy, social influence and facilitating conditions. Not only that, [32] claimed that, the main hindrance to the use of ICT is the complexity of their organizational structure in situations where the complexity of the environment impacted the use of ICT for effective integration and use of market information. Therefore, all these factors should be addressed well by the SME owners in order to ensure that they use ICT for their business' sustainable growth [49].

\section{Impact of ICT Diffusion in SME}

The use of ICT has become a necessity in today's business activities but there is still limited usage of ICT among businesses in Malaysia especially in rural areas [41]. This is a worrying situation as SMEs who do not adopt ICT will face difficulties in making the company visible to larger markets and to ensure sustainability. The study by [33] found that lack of access to ICT hindered Malaysia's SME to business' innovation growth. A research by [17] argue that SMEs, led by owners who are lack in basic knowledge in ICT, will lose their potential in their business. ICT contributes significantly to today's business transactions. Thus, SMEs are encouraged to adapt their purchases online so that with these trading platforms, they will enable all types of customer orders [36] and, in turn, increase the company's revenue and profitability. SMEs are also encouraged to continue to use ICT as it can generate effective business plans, access databases, and improve communication and social networks [50]. She added, the global environment is exposed to current challenges that should not be overlooked. The use of ICT has provided many opportunities for SMEs to avoid this challenge and maintain a sustainable competitive advantage by utilizing existing resources.

\section{E. Thematic Analysis}

Each qualitative research approach has specific techniques for controlling, documenting, and evaluating data analysis processes. The researcher is responsible to ensure the accuracy and relevancy of the said technique. Research by [10] had developed Thematic Analysis which was later applied in various fields of study. According to them, Thematic Analysis is the process of identifying patterns or themes in qualitative data. The goal of Thematic Analysis is to identify themes from the important data, and use this theme to address an issue in research. Thematic Analysis method not only summarizes the data, but also interprets and understands it better. Interview methods have been identified as the main method for finding themes. They have also listed six phases in doing the thematic analysis. Table I shows the phases and the descriptions of Thematic Analysis.

1) Phase 1: Familiarizing Yourself with the Data: The first step in qualitative analysis by [10] is to read and understand the transcript. The researcher should understand all the data that may be useful to make notes and make an initial impression.

TABLE I. Thematic ANAlysis Phases by [10]

\begin{tabular}{|l|l|}
\hline Phase & Description \\
\hline $\mathbf{1}$ & Familiarizing yourself with the data \\
\hline $\mathbf{2}$ & Generating initial codes \\
\hline $\mathbf{3}$ & Searching for themes \\
\hline $\mathbf{4}$ & Reviewing potential themes \\
\hline $\mathbf{5}$ & Defining themes \\
\hline $\mathbf{6}$ & Producing the report \\
\hline
\end{tabular}


2) Phase 2: Generating Initial Codes: In this phase, [10] highlight that researcher needs to manage the data in a meaningful and systematic way to reduce the amount of data into a more focused meaning. Researcher needs to encode each segment of the relevant data on the research question and use the open code when it does not have a pre-set code but develop and modify the code through the coding process. After taking the first step, researcher needs to discuss and develop some introductory ideas about the code. Then, setting up the transcript code is done separately. Encoding is performed on each segment of the relevant text to address the research question. The code is then compared and discussed before moving to another transcript. Researcher has the options to manually use either a printed transcript and a pen or to use qualitative data analytics software such as ATLAS.ti and Nvivo which is useful when dealing with large data sets. According to [11], Microsoft Excel can also be used to code and identify themes.

3) Phase 3: Searching for Teams: As previously defined by [10], themes are patterns that capture something important about data from research questions. If there is a very small data set, there might be similar data between the encoding level and the initial theme identification level. In this case we are looking at codes that eventually become the theme. At the end of this step, the code has been organized into a broader theme that seems to say something specific about this research question. This theme is mostly descriptive, which is to illustrate the patterns in the data related to the research questions. Most codes are associated with one theme, though some are linked to more than one.

4) Phase 4: Reviewing Potential Themes: The study by [10] defines this phase for study, refine and develop the preliminary themes identified in Phase 3. At this point, it is useful to collect all the data related to each theme and classify them by colors and consider the importance. The next step is to figure out how the theme works in one single interview and across all interviews. The themes should be clear and they should be different from each other.

5) Phase 5: Defining Themes: This is the final refinement of the theme which [10] set the goal to identify the essence of the theme; themes that you want to talk about, if there are subthemes, how they interact and relate to the main themes and each other. In this analysis, feedback is a comprehensive theme rooted in other themes.

6) Phase 6: Producing the Reports: Finally, the results of this thematic analysis will be written in the form of a report.

\section{F. Advantages of Thematic Analysis}

Thematic Analysis is a qualitative method that can be easily learnt because it includes complete methods and procedures [10]. Author in [24] argues that this method can summarize key features in large data sets because the researcher needs to be more structured in handling data and producing a good report. This clearly demonstrates that the method provides unique flexibility according to the research questions and data forms developed by the researcher. This
Thematic Analysis can be used to answer questions about their experiences, perspectives, practices, and behaviors. The qualitative data generated is through respondents in direct interaction or writing feedback to questions including secondary data sources. Next, it can be used for small and large data sets. Qualitative research should show that the analysis performed is reliable, accurate, consistent, and covers the whole through the recording, being systematic with complete details to prove that such a method of Thematic Analysis is reliable to use [34]. For the number of participants, [28] suggests that four is the minimum participant's number who came from different backgrounds to get clear picture on the issues faced.

\section{METHOdOLOGY OF FRAMEWORK}

In this paper, the study was conducted using qualitative method. Interviews had been done with twelve (12) SME owners and analysed using Thematic Analysis model developed by [10]. It is a method of identifying and analysing patterns in data sets and illustrating which themes are most important. The Thematic Analysis Model is suitable for this study as the process begins when the researcher identified potential issues during data collection [10]. Research by [3] had use different tool to analyze the data which is the Structural Equation Modelling (SEM). The quantitative statistical analysis is quite complex in terms of the procedure compared to Thematic Analysis.

\section{A. Materials}

The method used for this study was through interview sessions. Interviews were used to gather information on the reasons why SME owners in Malaysia are less involved in the use of ICT and technology in conducting their business activities. The first part of the interview form was initiated with informed consent requesting that each respondent agree to be recorded using a Sony ICD-UX543F digital voice recorder.

Next, demographic questions are provided in the second part of the interview form to gather more information about respondents and their businesses. The third part of the form is the questions used by the researcher in the interview session. The questions were used as the basis of the interview and the researcher had the right to add other questions depending on the answers provided by the respondents. This is to capture the real comments, reactions and realities faced by the respondents in sharing information about the usage of ICT and the day-to-day business situations and experience. After recording the data from the respondents, the researcher transcribed the data into digital text and used Microsoft Excel to store the data. Survey data were then analysed using Thematic Analysis method. The list of interview questions are as follows:

\section{Business Background}

1. How did you come up with the idea of starting the business?

2. What are the factors that drive you to set up the business?

3. How are you looking at competition today?

4. What actions / efforts did you take to overcome competition?

5. What do you do to increase knowledge / skills of the current business? 
6. What are the challenges that you have to face in the business?

7. Do you have a mentor in business and how does it affect the business?

\section{Factors affecting SME owners to adopt ICT}

1. Do you use ICT and technology in your business?

2. List the technologies used in this business.

3. What is your opinion on the usage of ICT?

4. Are you aware of the benefits of ICT and technology?

5. Have you ever attended courses that involve the usage of ICT?

6. How did they invite you to attend this course?

7. Do you think the course helped you to increase the usage of ICT?

8 . Do you agree with the content provided by the course?

9. Before attending a course, did you know what will be taught?

10. What is the duration of the course?

11. Give your personal opinion on the courses you have attended.

12. What are the barriers in you in adopting ICT in your business?

\section{B. Participants}

A total of $12 \mathrm{SME}$ owners agreed to participate in this study. All respondents were randomly selected after identifying their personal and business backgrounds. The male respondents were $3(25 \%)$ and the women were $9(75 \%)$ as shown in Fig. 1. The diagram below shows infographics distributions by their respective groups.

Fig. 2 illustrates the respondents' ages ranged from 32 to 63 (Mean: 45.25; Standard Deviation: 11.371).

Fig. 3 demonstrates the higher education levels for all respondents. They range from SPM (25\%), Certificate (8.33\%), Diploma (41.67\%) and Bachelor's Degree (25\%).

Fig. 4 shows the respondent's type of business which shows $33.33 \%$ based on products and $66.67 \%$ by services.

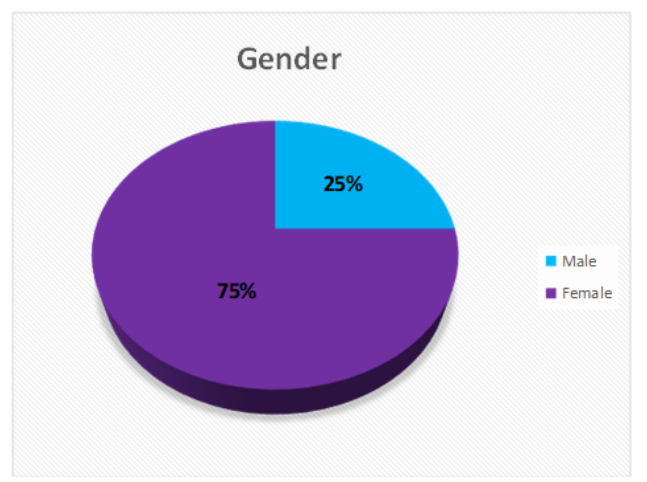

Fig. 1. Distribution of Respondents by Gender.

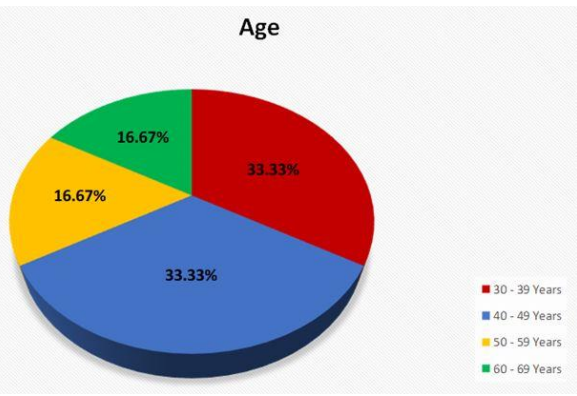

Fig. 2. Distribution of Respondent's Age.

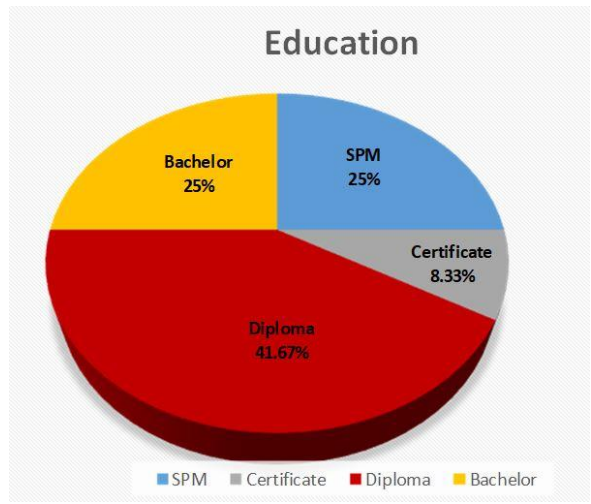

Fig. 3. Distribution of Respondent's Education.

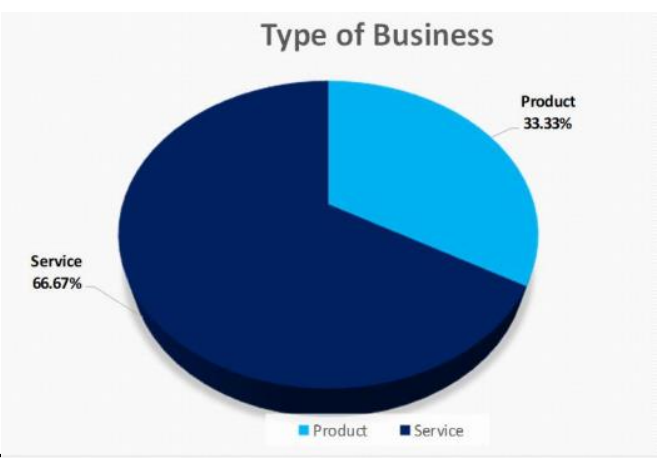

Fig. 4. Distribution of Respondent's Type of Business.

All respondents have been in business for 3 to 43 years. Fig. 5 illustrates the percentages of the years of services. $50 \%$ of the respondents had been in business from 1 to 15 years, $33.34 \%$ from 16 to 30 years and $16.66 \%$ from 31 to 45 years.

Table II shows the background details of all respondents. The details are the respondent's age, education, years of business establishments, type of business and the business they are running. The twelve (12) respondents came from various business backgrounds. Their age ranges from 32 to 63 years old. The year of establishments started from 1977 to 2015. The type of business that they run fall under the category of product $(33.33 \%)$ and services $(66.67 \%)$. Details are as follows:

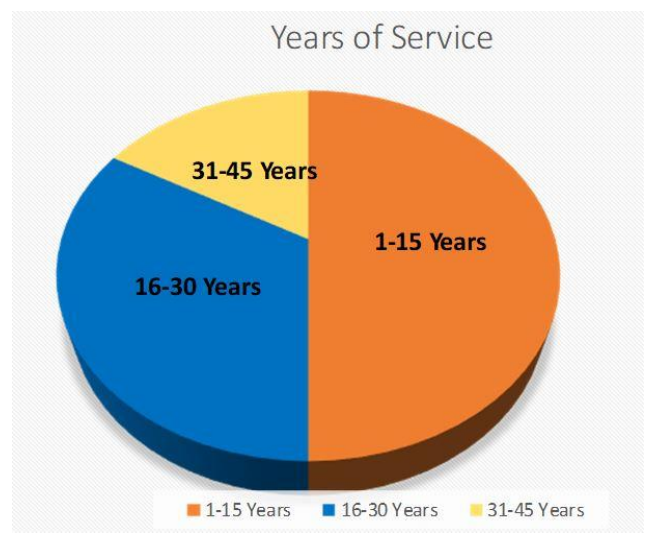

Fig. 5. FDistribution of Respondent's Years of Services. 
TABLE II. BACKGROUND DETAILS OF THE 12 RESPONDENTS

\begin{tabular}{|c|c|c|c|c|c|}
\hline Respondents & Age & Education & Year of Establish-ment & Type of Business & Business \\
\hline I1 & 47 & Certificate & 2013 & Service & Tailor \\
\hline $\mathrm{I} 2$ & 32 & Bachelor & 2015 & Product & Baby and Kids Products \\
\hline I3 & 63 & Bachelor & 2001 & Product & Used Cars \\
\hline I4 & 37 & Diploma & 2017 & Service & Barber \\
\hline I5 & 32 & Diploma & 2010 & Service & Beauty Salon \\
\hline I6 & 32 & Diploma & 1989 & Product & Bread and Pastries \\
\hline I7 & 61 & Diploma & 1977 & Product & Retails \\
\hline I8 & 56 & SPM & 1992 & Service & Catering \\
\hline I9 & 49 & SPM & 2011 & Service & Asam Pedas Restaurant \\
\hline $\mathrm{I} 10$ & 54 & Diploma & 1998 & Service & Tomyam Restaurant \\
\hline I11 & 40 & Bachelor & 1996 & Service & Law Firm \\
\hline $\mathrm{I} 12$ & 40 & SPM & 1997 & Service & Rental Houses \\
\hline
\end{tabular}

\section{Procedure}

This study was conducted using the interview method. The requirement for the respondents is SME owners who have been in business for more than 3 years by selling products or offering services. The selection of respondents was done randomly and business was conducted around Kuala Lumpur and Selangor, Malaysia. The researcher contacted the respondents and set an appointment. After setting up the place and time, both researcher and respondent met. The researcher described the study to be followed and the respondents were then asked to sign the consent form to allow the interview to be recorded and to fill out personal and business information on both forms. During the interview, the researcher used questions in the third section of the form and occasionally added questions depending on the answers and the responses provided by the respondents. As a token of appreciation, the researcher presented an Aeon voucher worth RM20 at the end of the interview. The same process was repeated until the 12th respondent.

1) Phase 1: Familiarizing Yourself with the Data: Upon completion of the interview, the researcher collects all audio data and upload the file to a laptop and created a set of storage files for security purposes. All twelve (12) audio data were then transcribed into words using Microsoft Excel software. The Excel data was then printed, and repeated readings were used to understand the details of the interviews.

2) Phase 2: Generating Initial Codes: Based on the set questions being asked during the interview session, the research attempted to obtain a starting code based on the answers provided by the respondents. The researcher then reduced these data to mo focused and important data. After generating nearly nine types codes and classifying them using different pencil colors, they we then passed on to the second and subsequent transcript.

3) Phase 3: Searching for Themes: After identifying the starting code, the third phase was conducted to find themes by assembling codes and formed the same set of data sets for each transcript.
4) Phase 4: Reviewing Potential Themes: After finding the theme, the researcher modified and developed the initial theme and revised it to meet the objectives of this study. Data was then reviewed repeatedly and stored only for the sake of importance. The theme should be clear with the objectives of the study and should be found in all twelve (12) transcripts.

5) Phase 5: Defining Themes: The researcher then analysed and determined the themes and then searched for sub-themes where the data interacted with the main themes in the data set.

6) Phase 6: Producing the Report: After obtaining codes, themes, sub-themes and sub sub-themes, the researcher then formulated a model framework based on the findings from the study. A report was produced that includes the study objectives, literature review, methodology, analysis, results and comprehensive discussion on this thematic analysis study.

\section{EXPERIMENTAL RESULTS AND FINDINGS}

The thematic analysis produces several factors that contribute to SME owners on ICT acceptance. Fig. 6 illustrates the analysis of the Factors Affecting SME Owners in Adopting ICT in their business. The analysis is divided into two (2) central themes which are Internal and External Factors. For Internal Factors, the researcher identified two (2) sub-themes which are Company and SME Owners. For Company, the factors are due to lack of capital, depending on company's age, less skilled workers and mostly because they run their family business. For SME Owner factors, the lists are ack of time, education background, owner's perception and oyner's bad experiences with ICT usage. Internal factors relate to everything that beyond the company's control. For External Factors, they are divided into two (2) sub-themes Which are Technology and Regulators. Under Technology, the factors that contributed to the lack of ICT adoption are because of the system's high cost, complicated systems and the doubt on the system's security and stability. For Regulators, the factors are to the government's initiatives, issues in the skills enhancement courses and there is no urgency to adopt ICT in certain industries. 


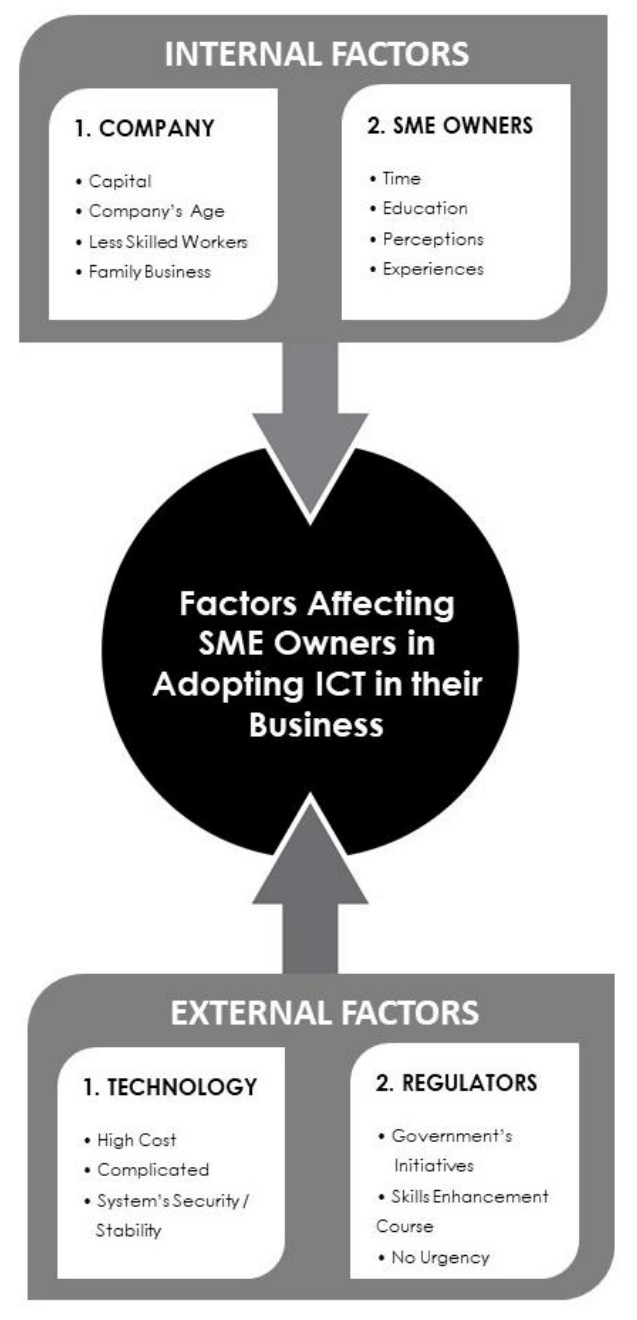

Fig. 6. Factors Affecting SME Owners in Adopting ICT in their Business.

Table III is the analysis using the Thematic Analysis method to identified the themes. It is setup with the codes derived by the researcher according to same set of answers given by the respondents. Researcher identified two (2) respondents were saying about the factors that makes they didn't opt to use ICT which was the age of the company. They started the business early and they claimed that the company and their age had affected the decision to use the ICT. Below is the selected narrative:

"We're actually very old and traditional. I didn't use to learn ICT" - Respondent 8

For the code of lack of capital, seven (7) respondents were quoting the similar reasons. The main constraints are the limited cost and capital that makes them choose not to use ICT in their business. Below are the selected narratives:

"It's fast, it's easy but it's a budget issue, which means financial constraints" - Respondent 1

"One of them is the cost" - Respondent 2

\section{"Ok, I think it's financial" - Respondent 5}

Four (4) of the respondents agree that the next factors are the lack of ICT Skilled Workers as per below narratives:

"Challenge here is to train our staff" - Respondent 2

"We want to go that way but because of the staff constraints, nobody can operate it" - Respondent 7

"But the limitation is our 'smart' workers. So it doesn't work as efficient as I wish" - Respondent 10

"We have to have people who are experts in accounting" Respondent 12

While another four (4) respondents stating that they run their family business and prefer the traditional way of handling business. The narrative is as below:

"This is a family business so my father-in-law likes the traditional way" - Respondent 12

For the sub-theme of Owner, the derivation started from the coding of lack of time because of the busy work schedule. Three (3) respondents agreed that time is their main constraints that hinder them to use an ICT in their business operations as per the following narratives:

"if there is any (training), I can but I need to look at my schedule" - Respondent 6

"We want to standardize our menu but the time limits us" - Respondent 10

"Time constraints for me to do that" - Respondent 12

Four (4) respondents quoted that their knowledge to ICT is limited and relate to their education backgrounds. The narratives are as follows:

"Limited knowledge" - Respondent 1

"One without knowledge" - Respondent 3

"because there is limited knowledge, there is no one to teach" - Respondent 5

"In fact Kak Lin is not very expert. So, I need to get my children to help me to use ICT" - Respondent 9

For the sub sub-theme for perception, three (3) respondents shared their bad perceptions towards using ICT in their business. They had negative thoughts generally on being scammed as per below narratives:

"People can cheat us; we don't know them" Respondent 1.

"We are afraid to use all this ICT thing if scammers still exist" - Respondent 3

"I've heard so many negative things from my customers" Respondent 9

It was then related to the next code which is real experiences and three (3) of the respondents revealed that they had been cheated and had suffered from loss. The narratives are as below: 
TABLE III. ANALYSIS FOR FACTORS INFLUENCING SME OWNERS IN ADOPTING ICT IN BUSINESS

\begin{tabular}{|c|c|c|c|c|c|}
\hline THEME & $\begin{array}{l}\text { SUB- } \\
\text { THEME }\end{array}$ & $\begin{array}{l}\text { SUB SUB- } \\
\text { THEME }\end{array}$ & CODE & NARRATIVE & $\begin{array}{l}\text { RESPON- } \\
\text { DENT }\end{array}$ \\
\hline \multirow{4}{*}{ Internal } & \multirow{4}{*}{ Company } & $\begin{array}{l}\text { Company's } \\
\text { Age }\end{array}$ & $\begin{array}{l}\text { Traditional and } \\
\text { old companies }\end{array}$ & $\begin{array}{l}\text { "In 2001, the business that I thought was selling cars" - R3 } \\
\text { "We're actually very old and traditional. I didn't use to learn ICT" - R8 }\end{array}$ & $\mathrm{R} 3, \mathrm{R} 8$ \\
\hline & & Capital & Lack of capital & $\begin{array}{l}\text { "It's fast, it's easy but it's a budget issue, which means financial } \\
\text { constraints" - R1 } \\
\text { "One of them is the cost" - R2 } \\
\text { "Ok, I think it's financial" - R5 } \\
\text { "I want the system cheap but also has to be functional" - R7 } \\
\text { "The challenge when we do business is the capital is at our own cost and } \\
\text { never borrow at all. So,we start with small amount"- R9 } \\
\text { "I'm thinking back to financial constraints" - R10 } \\
\text { "Cost is one thing; we have to buy software" - R12 }\end{array}$ & $\begin{array}{l}\text { R1, R2, R5, } \\
\text { R7, R9, R10, } \\
\text { R12 }\end{array}$ \\
\hline & & $\begin{array}{l}\text { Less Skilled } \\
\text { Workers }\end{array}$ & $\begin{array}{l}\text { Lack of ICT } \\
\text { skilled workers }\end{array}$ & $\begin{array}{l}\text { "The challenge here is to train our staff" - R2 } \\
\text { "We want to go that way but because of the staff constraints, nobody can } \\
\text { operate it" - R7 } \\
\text { "But the limitation is our 'smart' workers. So it doesn't work as efficient as } \\
\text { I wish"- R10 } \\
\text { "We have to have people who are experts in accounting" - R12 }\end{array}$ & $\begin{array}{l}\mathrm{R} 2, \mathrm{R} 7, \mathrm{R} 10, \\
\mathrm{R} 12\end{array}$ \\
\hline & & $\begin{array}{l}\text { Family } \\
\text { Business }\end{array}$ & $\begin{array}{l}\text { Family } \\
\text { Business } \\
\text { History }\end{array}$ & $\begin{array}{l}\text { "My dad used to make bread from Muar. He quit his military service and } \\
\text { started making bread out of curiosity" - R6 } \\
\text { "The store is part of family business, so after he retired, we operated from } \\
1977 \text { till now" - R7 } \\
\text { "Back then, my mother-in-law ran a small house-to-house cooking for } \\
\text { small wedding" - R8 } \\
\text { "This is family business so my father-in-law like the traditional way" - } \\
\text { R12 }\end{array}$ & $\begin{array}{l}\text { R6, R7, R8, } \\
\text { R12 }\end{array}$ \\
\hline \multirow{4}{*}{ Internal } & \multirow{4}{*}{ Owner } & Time & $\begin{array}{l}\text { Lack of time } \\
\text { because of the } \\
\text { busy work }\end{array}$ & $\begin{array}{l}\text { "if there is any (training), I can but I need to look at my schedule" - R6 } \\
\text { "We want to standardize our menu but the time limits us" - R10 } \\
\text { "Time constraints for me to do that" - R12 }\end{array}$ & R6, R10, R12 \\
\hline & & Education & $\begin{array}{l}\text { SME owners' } \\
\text { knowledge of } \\
\text { ICT is limited }\end{array}$ & $\begin{array}{l}\text { "Limited knowledge" - R1 } \\
\text { "One without knowledge" - R3 } \\
\text { "because there is limited knowledge, there is no one to teach" - R5 } \\
\text { "In fact Kak Lin is not very expert. So, I need to get my children to help } \\
\text { me to use ICT" - R9 }\end{array}$ & R1, R3, R5, R9 \\
\hline & & Perception & $\begin{array}{l}\text { There are many } \\
\text { negative } \\
\text { responses to } \\
\text { ICT usage }\end{array}$ & $\begin{array}{l}\text { "People can cheat us; we don't know them" - R1 } \\
\text { "We are afraid to use all this ICT thing if scammers still exist" - R3 } \\
\text { "I've heard so many negative things from my customers" - R9 }\end{array}$ & R1, R3, R9 \\
\hline & & Experience & $\begin{array}{l}\text { Previous } \\
\text { experience has } \\
\text { made SMEs } \\
\text { choose not to } \\
\text { use ICT }\end{array}$ & $\begin{array}{l}\text { "Many scammers, they called me and said they are lawyers and I didn't } \\
\text { pay for my debts and many more cases" - R3 } \\
\text { "I’ve been scammed through FB; the loss was RM700" - R5 } \\
\text { "I've been cheated; not once but twice" - R9 }\end{array}$ & R3, R5, R9 \\
\hline \multirow{2}{*}{ External } & \multirow{2}{*}{ Technology } & High Cost & $\begin{array}{l}\text { The installation } \\
\text { of } \\
\text { infrastructure } \\
\text { and ICT } \\
\text { equipment is } \\
\text { costly }\end{array}$ & $\begin{array}{l}\text { "The biggest downside is the cost of the ICT products"-R4 } \\
\text { "I think the cost is a bit high for me" - R5 } \\
\text { "See how much it costs, I can't afford if I have to pay a lot" - R7 } \\
\text { "The ICT is a good help but is quite expensive" - R10 }\end{array}$ & $\begin{array}{l}\mathrm{R} 4, \mathrm{R} 5, \mathrm{R} 7, \\
\mathrm{R} 10\end{array}$ \\
\hline & & Complicated & $\begin{array}{l}\text { Complex } \\
\text { interface }\end{array}$ & $\begin{array}{l}\text { "ICT systems are difficult. It's not easy to remember interfaces in the } \\
\text { system" - R1 } \\
\text { "I don't want it to be complex because the one that we had were so } \\
\text { complicated to me " - R7 } \\
\text { "The system is complicated for us because it always has to be updated or } \\
\text { renew (license)" - R9 }\end{array}$ & $\mathrm{R} 1, \mathrm{R} 7, \mathrm{R} 9$ \\
\hline
\end{tabular}




\begin{tabular}{|c|c|c|c|c|c|}
\hline \multirow{4}{*}{ External } & Technology & $\begin{array}{l}\text { System's } \\
\text { Security / } \\
\text { Stability }\end{array}$ & $\begin{array}{l}\text { Doubts on the } \\
\text { security and } \\
\text { stability of the } \\
\text { ICT system }\end{array}$ & $\begin{array}{l}\text { "for example in the security of the ICT system, sometimes we don't know } \\
\text { it" - R1 } \\
\text { "Sometimes disadvantage is the ICT's security. Not sure about security" - } \\
\text { R3 } \\
\text { "I doubt the stability of this ICT system" - R4 } \\
\text { "I am afraid he will say:" You have to be more careful, as you might lose } \\
\text { your money easily" - R9 }\end{array}$ & R1, R3, R4, R9 \\
\hline & \multirow{3}{*}{ Regulators } & $\begin{array}{l}\text { Government } \\
\text { Initiative }\end{array}$ & $\begin{array}{l}\text { Opinions on } \\
\text { government } \\
\text { initiatives in } \\
\text { promoting the } \\
\text { use of ICT }\end{array}$ & $\begin{array}{l}\text { "Kasih Ibu Smart Selangor (KISS). Anyone who has that privilege card } \\
\text { can come here and can buy anything" - R7 } \\
\text { " I want them badly (training). Those things are necessary right now. If } \\
\text { you don't know the updates, then you will be left behind" - R9 } \\
\text { "To me, if you want to teach people, you don't look down on them. Even } \\
\text { if he sells banana fritters, you have to teach them how to run their } \\
\text { business well. Maybe they can pack nicely" - R10 } \\
\text { "In my opinion, it is good and we welcome the government's initiative to } \\
\text { create more effective lawyers especially in dealing with ICT" - R11 }\end{array}$ & $\begin{array}{l}\text { R7, R9, R10, } \\
\text { R11 }\end{array}$ \\
\hline & & $\begin{array}{l}\text { Skills } \\
\text { Enhancement } \\
\text { Course }\end{array}$ & $\begin{array}{l}\text { Feedback on } \\
\text { courses taken }\end{array}$ & $\begin{array}{l}\text { "It is compulsory for us to attend } 21 \text { days of very challenging mental and } \\
\text { physical courses in order for us to get the funds" - R1 } \\
\text { "Sometimes this course requires payment" - R1 } \\
\text { "I thought that anything related to learning ICT needs payment" - R9 } \\
\text { "but the input they gave us is nothing. To me, they didn't teach us } \\
\text { anything" - R10 }\end{array}$ & R1, R9, R10 \\
\hline & & No Urgency & $\begin{array}{l}\text { No } \\
\text { requirements } \\
\text { and authorities } \\
\text { do not } \\
\text { encourage to } \\
\text { use ICT }\end{array}$ & $\begin{array}{l}\text { "because the need is not urgent" - R11 } \\
\text { "there is no need/urgency and demand for such things (ICT)" - R12 }\end{array}$ & $\mathrm{R} 11, \mathrm{R} 12$ \\
\hline
\end{tabular}

"Many scammers, they called me and said they are lawyers and I didn't pay for my debts and many more cases" Respondent 3

"I've been scammed through FB; the loss was RM700" Respondent 5

"I've been cheated; not once but twice" - Respondent 9

For the External Factor which is Technology, the derivation was started off with the finding of coding stated that the installation of infrastructure and ICT equipment is costly. Four (4) respondents gave the same feedback which is the ICT are expensive and they cannot afford the cost.

"The biggest downside is the cost of the ICT products"Respondent 4

"I think the cost is a bit high for me" - Respondent 5

"See how much it costs, I can't afford if I have to pay a lot" - Respondent 7

"The ICT is a good help but is quite expensive" Respondent 10

Next coding is the complex interface that makes the ICT system complicated. Three (3) respondents quoted that they had been facing the complex system and they find it difficult. The narratives are as below:

"ICT systems are difficult. It's not easy to remember interfaces in the system" - Respondent 1

"I don't want it to be complex because the one that we had was so complicated to me " - Respondent 7

"The system is complicated for us because it always has to be updated or renewed (license)" - Respondent 9
Four (4) respondents had doubts on the security and stability of the ICT system that falls under the Technology sub-theme. The narratives are as follows:

"for example in the security of the ICT system, sometimes we don't know it" - Respondent 1

"Sometimes disadvantage is the ICT's security. Not sure about security" - Respondent 3

"I doubt the stability of this ICT system" - Respondent 4

"I am afraid he will say:" You have to be more careful, as you might lose your money easily" - Respondent 9

For the sub-theme of Regulators, four (4) respondents had given good opinions to the code of government's initiatives in promoting the usage of ICT. The narratives are as below:

"Kasih Ibu Smart Selangor (KISS). Anyone who has that privilege card can come here and can buy anything" Respondent 7

" I want them badly (training). Those things are necessary right now. If you don't know the updates, then you will be left behind" - Respondent 9

"To me, if you want to teach people, you don't look down on them. Even if he sells banana fritters, you have to teach them how to run their business well. Maybe they can pack nicely" - Respondent 10

"In my opinion, it is good and we welcome the government's initiative to create more effective lawyers especially in dealing with ICT" - Respondent 11

Unfortunately, for the code of feedback on the courses taken, three (3) respondents argued that, the content and the procedure of the courses they attended. The narratives are as below: 
"It is compulsory for us to attend 21 days of very challenging mental and physical courses in order for us to get the funds" - Respondent 1

\section{"Sometimes this course requires payment" - Respondent 1}

"I thought that anything related to learning ICT needs payment" - Respondent 9

"but the input they gave us is nothing. To me, they didn't teach us anything" - Respondent 10

For the sub sub-theme of No Urgency under regulators, the code was no requirements and authorities do not encourage the usage of ICT. The researcher notes that, there are still industries that does not need the players (business) to use ICT to their operations and that make sense on why certain businesses did not opt to use ICT. The narratives are as below:

"because the need is not urgent" - Respondent 11

"there is no need/urgency and demand for such things (ICT)" - Respondent 12

\section{DISCUSSION}

Based on the interviews with twelve (12) SME owners, there are two (2) central themes that influence the use of ICT in business in Malaysia. Using Thematic Analysis method, the central themes are Internal and External factors. Table IV illustrate Internal factors include two sub-themes which are company and owner. These two sub-themes are divided into four sub sub-themes. The sub sub-themes for the company are the company's age, capital, less ICT skilled workers and family business while the sub sub-themes for the owner are the time, education, perception and experience.

For external factor, Table V illustrate the sub-themes are technology and regulators, which are divided into three sub sub-themes for each theme. For Technology, the sub-themes are high cost, complicated and system's security and stability. Meanwhile, the sub-themes for regulators are government initiatives, skilled enhancement courses and no urgency. These sub-themes and sub sub-themes were found after starting with the search for the code as the initial keyword.

The interview questions were varies and it is up to the researcher to ask more questions after the respondents had given their opinions. As a result from this Thematic Analysis method, the agenda and objectives in the same code are provided by all the owners of the SMEs who then formulated the themes, sub-themes and sub sub-themes in analyzing the results of this interview. The same foundation suggests that ICT usage factors would be better if they were being analyzed thoroughly, thus could increase the usage of ICT among the SME owners. The theme of internal factors of the company are the age of the company [20], [15], limited capital [39], [12], [7], less skilled workers [17] and family business [6], [18]. The derivation of these sub-themes indicated that the management should overcome all the problems arise hence will help to increase the ICT usage in their business. Author in [45] suggests that SME owners could find ways to manage the competitive and fast-paced technology by investing in ICT specifically to ensure that social networks such as strategic partners and customers are well maintained. In addition, SME owners must be proactive in preparing the entire organization so that all information and knowledge is readily available and essential for management to create a platform for employees to welcome change and support innovation [20]. To inculcate the business management skills among the generation nowadays, [22] suggested that the entrepreneurship education should be taught as early as in their high school.

Another themes of the owner's internal factors are time [39], education [14], perception [2] and experience. Most SME owners do not develop themselves and their companies with the advanced knowledge and thus their knowledge is rather limited especially in the field of ICT. This is agreed by [18] who said that the education contributes to the long-term effect in economic sector. Likewise, for the time factor, SME owners should spend more time discovering new ways of managing and developing new technologies that can elevate their business to a better position. SME owners have a significant impact on financial decisions [25] and business, therefore, they have to move forward and leave behind bad experiences [15] such as capital loss and negative perceptions related to the use of ICT as it will only making their business less competitive.

Then, the technology factors [29] are high cost [48], complicated system [21] and system's security and stability [46]. For SME owners, they want a user-friendly system and make it easier for them to manage their day-to-day business activities. Therefore, it is important for software developers to simplify their system's development and at reasonable cost because according to [38], IT solutions should be user-friendly and intuitive to learn. Security [21] and system stability are also factors that make SME owners less likely to use ICT because they fear that if they make mistakes, they will lose their money.

TABLE IV. INTERNAL FACTORS

\begin{tabular}{|l|l|l|}
\hline THEME & SUB-THEME & SUB SUB-THEME \\
\hline \multirow{4}{*}{ Company } & Company's Age \\
\cline { 3 - 3 } & & Capital \\
\cline { 3 - 3 } & & Less Skilled Workers \\
\cline { 3 - 3 } & & Family Business \\
\cline { 3 - 3 } & \multirow{4}{*}{ Owner } & Time \\
& & Education \\
& & Perception \\
\cline { 3 - 3 } & & Experience \\
\hline
\end{tabular}

TABLE V. EXTERNAL FACTORS

\begin{tabular}{|l|l|l|}
\hline THEME & SUB-THEME & SUB SUB-THEME \\
\hline \multirow{4}{*}{ External } & \multirow{3}{*}{ Technology } & High Cost \\
\cline { 3 - 3 } & & Complicated \\
\cline { 3 - 3 } & \multirow{3}{*}{ Regulators } & System's Security and Stability \\
\cline { 3 - 3 } & & Government Initiatives \\
\cline { 3 - 3 } & & Skilled Enhancement Courses \\
\cline { 3 - 3 } & & No Urgency \\
\hline
\end{tabular}


The themes of external factors of regulators are government initiatives [36] skills improvement courses [13], [27] and no urgency. The respondents welcomed any government initiative in promoting the use of ICT [14] among SME owners and thus increased their income in business. However, there were also feedback from respondents who wanted them to have useful inputs and knowledge that could be used for their business rather than being forced to attend the training in order to be selected to apply for grants or loan. Some even think they have to pay for the courses attended. Authorities are encouraged to provide a clear and comprehensive explanation to ensure all SME owners have the same information and can consider participating in the course if they can arrange their time and staff. In an effort to encourage SME owners to use ICT in their businesses, there are still sectors and areas of business that put no urgency in adopting ICT. Therefore, regulators should view ICT as an initiative that can save time and cost. From there, it can only be realized that the impact of the role of ICT is very important and impacting business.

\section{CONCLUSION}

This study was established to analyze the factors affecting Malaysian SME owners in adopting ICT in their businesses. Interview sessions were done with twelve (12) SME owners who run businesses around Kuala Lumpur and Selangor, Malaysia. Using the Thematic Analysis method, the researcher found that there were internal and external factors that led to less usage of ICT in SME's business activities. The derivation of the factors retrieved from the initial code that had been generated through all twelve (12) transcripts. The initial codes then led to the discoveries of sub-themes and themes. For internal factors, company and owners are the two main factors that affect the less usage of ICT in business. It is followed by the other two factors which are technology and regulators which falls under external factors. From these findings, owners and the management of a company may find it useful to ensure efforts and actions are taken into consideration to make the adoption of ICT in their business operation a success. This is due to the spike in the usage of ICT especially by the customers during this advanced technology time. Businesses are urged to take necessary actions to ensure the adoption of ICT is at a higher rate as well as to maintain the sustainability of their business. The suggestion for future research is to include more participants with different SME owner's age and businesses in rural areas.

\section{REFERENCES}

[1] Abazi, B. (2016). An approach to the impact of transformation from the traditional use of ICT to the Internet of Things: How smart solutions can transform SMEs. IFAC PapersOnLine, 49(29), 148-151.

[2] Abualrob, A. A., \& Kang, J. (2016). The barriers that hinder the adoption of e-commerce by small businesses: Unique hindrance in Palestine. Information Development, 32(5), 1528-1544.

[3] AlBar, A. M., \& Hoque, M. R. (2019). Factors affecting the adoption of information and communication technology in small and medium enterprises: A perspective from rural Saudi Arabia. Information Technology for Development, 25(4), 715-738.

[4] Ali, M., Zhou, L., Miller, L., \& Ieromonachou, P. (2016). User resistance in IT: A literature review. International Journal of Information Management, 36(1), 35-43.
[5] Amusan, L. M., Oloniju, L. I., Akomolafe, M., Makinde, A., Peter, N. J., Farayola, H., \& Osawaru, F. A. I. T. H. (2018). Adopting information and communication technology in construction industry. International Journal of Mechanical Engineering and Technology (IJMET), 9(1), 739746.

[6] Andriani, D.P., Putro,W.W., Sari,S. I. K., Putri, A., Aini, N., \& Anwar, A. A. (2019) Decision-making Model for Determinant Factors of Business Digital Platform Adoption by SMEs.

[7] Apulu, I., \& Latham, A. (2011). Drivers for information and communication technology adoption: A case study of Nigerian small and medium sized enterprises. International Journal of Business and Management, 6(5), 51.

[8] Baker, J. (2012). The technology-organization-environment framework. In Information systems theory (pp. 231-245). Springer, New York, NY.

[9] Banci Ekonomi 2016 - Profil PKS (2020, April 24), Retrieved from http://www.smecorp.gov.my

[10] Braun, V., \& Clarke, V. (2006). Using thematic analysis in psychology. Qualitative Research in Psychology, 3, 77-101.

[11] Bree, R. T., \& Gallagher, G. (2016). Using Microsoft Excel to code and thematically analyse qualitative data: a simple, cost-effective approach. AISHE-J: The All Ireland Journal of Teaching and Learning in Higher Education, 8(2).

[12] Bresnahan, T., \& Yin, P. L. (2017). Adoption of new information and communications technologies in the workplace today. Innovation policy and the economy, 17(1), 95-124.

[13] Bruque, S., \& Moyano, J. (2007). Organisational determinants of information technology adoption and implementation in SMEs: The case of family and cooperative firms. Technovation, 27(5), 241-253.

[14] Chatzoglou, P., \& Chatzoudes, D. (2016). Factors affecting e-business adoption in SMEs: an empirical research. Journal of Enterprise Information Management.

[15] Dholakia, R. R., \& Kshetri, N. (2004). Factors impacting the adoption of the Internet among SMEs. Small Business Economics, 23(4), 311-322.

[16] Di Cintio, M., Ghosh, S., \& Grassi, E. (2017). Firm growth, R\&D expenditures and exports: An empirical analysis of Italian SMEs. Research Policy, 46(4), 836-852.

[17] Elbeltagi, I., Al Sharji, Y., Hardaker, G., \& Elsetouhi, A. (2013). The role of the owner-manager in SMEs' adoption of information and communication technology in the United Arab Emirates.Journal of Global Information Management (JGIM), 21(2), 23-50.

[18] Fitzgerald, M.A., \& MuskeG. (2016). Family businesses and community development: the role of small business owners and entrepreneurs. Com. Development,47(4),412-430.

[19] Giotopoulos, I., Kontolaimou, A., Korra, E., \& Tsakanikas, A. (2017). What drives ICT adoption by SMEs? Evidence from a large-scale survey in Greece. Journal of Business Research, 81, 60-69.

[20] Gono, S., Harindranath, G., \& Özcan, G. B. (2016). The adoption and impact of ICT in South African SMEs. Strategic Change, 25(6), 717734.

[21] Harindranath, G., Dyerson, R., \& Barnes, D. (2008). ICT in Small Firms: Factors Affecting the Adoption and Use of ICT in Southeast England SMEs. In ECIS (pp. 889-900).

[22] Ishak, S., Omar, A. R. C., Al Bakri, F. M., \& Osman, L. H. (2018). Amalan pembelajaran dan kesannya terhadap pembentukan pengetahuan serta kemahiran perniagaan dalam kalangan Generasi Z (Learning practices and effect on the knowledge and skills development among $\mathrm{Z}$ generation). Geografia-Malaysian Journal of Society and Space, 14(1).

[23] Kapurubandara, M., \& Lawson, R. (2006). Barriers to Adopting ICT and e-commerce with SMEs in developing countries: An Exploratory study in Sri Lanka. University of Western Sydney, Australia, 82(1), 20052016.

[24] King, N. (2004). Using templates in the thematic analysis of text. In C. Cassell \& G. Symon (Eds.), Essential guide to qualitative methods in organizational research (pp. 257-270). London, UK: Sage.

[25] Klačmer Čalopa, M. (2017). Business owner and manager's attitudes towards financial decision-making \& strategic planning: Evidence from Croatian SMEs. Management: Journal of Contemporary Mgmt. Issues, 22(1),103-116 
[26] Kumar, D. M. (2020). Role of Information and Communication Technology in Business and Education. Studies in Indian Place Names, 40(71), 386-392.

[27] Lopez-Nicolas, C., \& Meroño-Cerdán, Á. L. (2009). The impact of organizational culture on the use of ICT for knowledge management. Electronic Markets, 19(4), 211.

[28] Maree, J. G. (2015). Career construction counseling: A thematic analysis of outcomes for four clients. Journal of Vocational Behavior, 86, 1-9.

[29] Mohamad, N., \& Ishak, M. S. (2013). Pengaruh faktor organisasi dan faktor teknologi terhadap penerimaan media sosial sebagai medium pemasaran penginapan bajet.

[30] Muriithi, S. (2017). African small and medium enterprises (SMEs) contributions, challenges and solutions.

[31] Napitupulu, D., Syafrullah, M., Rahim, R., Abdullah, D., \& Setiawan, M. I. (2018, April). Analysis of user readiness toward ICT usage at small medium enterprise in south tangerang. In Journal of Physics: Conference Series (Vol. 1007, No. 1, p. 012042). IOP Publishing.

[32] Neirotti, P., Raguseo, E., \& Paolucci, E. (2018). How SMEs develop ICT-based capabilities in response to their environment. Journal of Enterprise Information Management. Alam, S. S., \& Noor, M. M. (2009). ICT adoption in small and medium enterprises: An empirical evidence of service sectors in Malaysia. International Journal of Business and management, 4(2), 112-125.

[33] Nor, N. G. M., Bhuiyan, A. B., Said, J., \& Alam, S. S. (2017). Innovation barriers and risks for food processing SMEs in Malaysia: A logistic regression analysis. Geografia-Malaysian Journal of Society and Space, 12(2).

[34] Nowell, L. S., Norris, J. M., White, D. E., \& Moules, N. J. (2017). Thematic analysis: Striving to meet the trustworthiness criteria. International Journal of Qualitative Methods, 16(1), 1609406917733847.

[35] Omar, F. I., Othman, N. A., Salleh, M. A. M., \& Abdullah, N. H. (2018). Affective Need of ICT in Improving Business Performance among Malay Women Entrepreneur. International Journal of Academic Research in Business and Social Sciences, 8(6).

[36] Osorio-Gallego, C. A., Londoño-Metaute, J. H., \& López-Zapata, E. (2016). Analysis of factors that influence the ICT adoption by SMEs in Colombia. Intangible Capital, 12(2), 666-732.

[37] Othman, N., \& Othman, S. H. (2017). The perceptions of public university students of entrepreneurship education in Malaysia. International Business Mgmt., 11(4), 865-873.

[38] Rahayu, R., \& Day, J. (2016). E-commerce adoption by SMEs in developing countries: evidence from Indonesia. Eurasian Business Review, 7(1), 25-41. doi:10.1007/s40821-016-0044-6

[39] Rahbi, A. L., \& Abdullah, H. S. (2017). Factors influencing social media adoption in small and medium enterprises (SMEs) (Doctoral dissertation, Brunel Univ. London).
[40] Ramayah, T., Ling, N. S., Taghizadeh, S. K., \& Rahman, S. A. (2016). Factors influencing SMEs website continuance intention in Malaysia. Telematics and Informatics, 33(1), 150-164.

[41] Rashid, S. M. R. A. (2016). Petunjuk penggunaan ICT dan persepsi masyarakat terhadap penggunaan ICT dalam kalangan usahawan wanita luar bandar (Instructions for Use of ICT and Public Perceptions of ICT Use Among Rural Women Entrepreneurs). Geografia-Malaysian Journal of Society and Space, 12(13).

[42] Robinson, M., Imran, A., \& Barlow, M. (2018, April). Impact of Macrolevel Regulations on Micro-level (Individual) Use of ICT: A case of mobile services in India. In Proceedings of the 11th International Conference on Theory and Practice of Electronic Governance(pp.175182).

[43] Rozmi, A. N. A., Bakar, M. I. A., Hadi, A. R. A., \& Nordin, A. I. (2019, November). Investigating the Intentions to Adopt ICT in Malaysian SMEs Using the UTAUT Model. In International Visual Informatics Conference (pp. 477-487). Springer,Cham.

[44] Saleem, F., Salim, N., Altalhi, A. H., Ullah, Z., AL-Malaise ALGhamdi, A., \& Mahmood Khan, Z. (2020). Assessing the effects of information and communication technologies on organizational development: business values perspectives. Information Technology for Development, 26(1), 54-88.

[45] Scuotto, V., Santoro, G., Bresciani, S., \& Del Giudice, M. (2017). Shifting intra \& inter-organizational innovation processes towards digital business: an empirical analysis of SMEs. Creativity and Innovation Mgmt., 26(3), 247-255.

[46] Tan, K. S., Chong, S. C., Lin, B., \& Eze, U. C. (2009). Internet-based ICT adoption: evidence from Malaysian SMEs. Industrial Management \& Data Systems.

[47] Ukata, P. F., Adejola, B. C., \& Okoye, A. I. (2018). Business Education StudentsICT Learning Experiences and Programme Satisfaction in Rivers State Universities. World Journal of Innovation and Modern Technology, 2, 9-34.

[48] Yahaya, J. H., Ibrahim, S. R. A., Hamdan, A. R., Deraman, A., \& Jusoh, Y. Y. (2018). Model Kesediaan Pelaksanaan Teknologi Maklumat untuk PKS Ke Arah Era Revolusi Industri 4.0. Jurnal Pengurusan (UKM Journal of Management), 54.

[49] Yunis, M., El-Kassar, A. N., \& Tarhini, A. (2017). Impact of ICT-based innovations on organizational performance. Journal of Enterprise Information Management.

[50] Yunis, M., Tarhini, A., \& Kassar, A. (2018). The role of ICT and innovation in enhancing organizational performance: The catalysing effect of corporate entrepreneurship. Journal of Business Research, 88, 344-356. 